\title{
Humboldt, Mickey Mouse and Current European Reseach Programmes - or Where are the Women in all This?
}

\section{Af Gabriele Griffin}

Hvad kan kønsforskningen tilføre det europaiske projekt? Og hvad kan de europaiske forskningsprogrammer tilbyde kønsforskningen? Konsforskningen og det europeiske projekt har falles intentioner nair det galder udviklingen af ny viden og forskning på tverfagligt grundlag. Og konsforskning rummer nye begrebsmessige kontekster til at forstå europeiske nogleord som medborgerskab, velferdsstat, familie, race og etnicitet.

Det nye 6. rammeprogram for forskning har dog ikke gjort det lettere for konsforskere at koble sig på. Kon er til stede overalt og ingen steder, bl.a. som folge af mainstreamingstrategien.

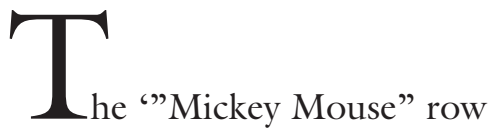
[was] revived' in the spring of 2003 in the UK according to the Times Higher Education Supplement ${ }^{1}$ when UK higher education minister Margaret Hodge suggested that high drop-out rates in some British universities are due to the 'Mickey Mouse degrees' those universities deliver, degrees that are supposedly 'poorly designed and lacking intellectual rigour.' Whereas in many European countries, post Bologna, Humboldt to Mickey Mouse encapsulates the fear of the shrinking degree - how can you do in three years what you used to do in five to seven? - in the UK, famously the inventor of the mini (skirt, car. . .), there is no fear of the bonsai degree. Thus as other European countries turn up the heat under their elasticated degrees, the UK contemplates the wide-scale implementation of the new-ish so-called Foundation degrees, twoyear degrees designed to widen access and achieve higher participation rates than the history of pre-university gate-keeping and 
elitism in British higher education has hitherto allowed. Brave new world.

Hodge's attack on Mickey Mouse degrees was about content rather than time taken to complete the degree. In the past twenty-five years such attacks which have usually been directed at quite particular social sciences and humanities degrees have been common in the UK. Cultural Studies, Media Studies, at one point Sociology and, most recently, Women's or Gender Studies ${ }^{2}$ have all borne the brunt of such attacks. Women's and Gender Studies has, since the period of its inception from the 1970s onwards, suffered constant gendered attacks questioning the specificity or otherwise of its subject domain, the intellectual rigour of its epistemological bases, the appropriateness and scientific rigour of its methods and methodologies. ${ }^{3}$

Despite these attacks gender research 4 has flourished, not just within Women's or Gender Studies but also as part of the mainstreaming of such research in more traditional disciplines. Where nation states have been slow to recognize Women's or Gender Studies as a discipline, international organizations such as the World Bank, the World Health Organization, and the United Nations, and supranational formations such as the European Union have unaltruistically but highly pragmatically recognized that the need to utilize women's potential as part of both agendas for social change and for wealth creation is crucial. They have been among the many international organizations which have supported gender or feminist research to a significant degree, and have helped to promote gender agendas through their research programmes.

In this article I shall therefore briefly explore the integration of gender and gender research into the new Framework 6 programme of the European Union, the similarities between Women's or Gender Studies and Europe as transformative projects, the European dimensions in Women's or Gender Studies, and the challenges gender researchers face in working within Framework 6.

\section{Gender Research in Framework 6}

One of the reasons why gender research has risen to some prominence is that the European Union has recognized that it is through interdisciplinarity that epistemological paradigms are often shifted and new research opened up. Women's or Gender Studies by its very interdisciplinary nature is thus in a prime position to facilitate the production of certain kinds of new knowledge. The EU's concerns with the four big E's - education, employment, economy, environment - go hand in hand with the understanding that to achieve certain kinds of new knowledge in contemporary societies means breaking out of the frames that hold the traditional disciplines in place. Thus the 2002-3 work programme of the Framework 6's Priority 7, 'Citizens and Governance in a Knowledge Based Society' is explicit in its recognition that such structures need to be opened up; under Topic 1.2, Knowledge dynamics and economic and societal development in Europe and in its regions, it asks that

"Research should address ways in which the generation and transmission of new knowledge could promote the integration of social sciences and humanities in Europe. At present, these research fields are strongly marked by their national emergence contexts; there are major limits and barriers to their integration within a European perspective. Research should analyse the forms of national, disciplinary and paradigmatic fragmentation of the social sciences and humanities in Europe and propose practicable means to overcome this fragmentation." 5

Women's and Gender Studies is in a privileged position in relation to this call since its birth at the interface of the social sciences and the humanities has meant that it has developed a history of working against the fragmentation described above 
in the face of much resistance. That resistance has, of course, not only been about the maintenance of the disciplinary boundaries which Women's Studies threatens but also about the recognition of the overt ideological and transformative project that Women's Studies represents. In that respect Women's Studies has similarities with the idea of Europe as a transformative project, intent upon creating new structures that will both maximize certain potentials through creating synergies and act as a bulwark against histories of discrimination that have led to many intra-European wars, genocides, the holocaust, and persecutions. It is thus possible, in the broadest sense, to draw a parallel between Europe's attempts to become Europe, a single entity, with some nation states more eager to join in this supranational venture than others, and Women's Studies' attempts to become a discipline.

Given this context we may ask both what does Women's Studies have to offer Europe and what can Europe offer women and Women's Studies? One thing which Women's Studies can offer Europe is a conceptual framework within which to understand the specificity of the European subject or citizen. One of the ways in which Europe differs significantly from the United States of America - one of two key countries against which the European Union measures its own progress - is its history of change, emblematized, for instance, in the current process of enlargement and in the division among diverse European countries in their attitudes towards a possible war with Iraq. Whereas Europe as idea, ideal and geopolitical reality has been the object of significant changes, not least in the twentieth century, the USA have operated in that same period largely as a stable entity. Europe, unlike the USA, consists of nation states, manifesting high degrees of internal diversity, polylingualism, and multiculturalism. It is thus not internally stable, and the issue of harmonizing this diversity and instability within the European Union is one of the greatest challenges Europeans face in the twenty-first century. Gender research has much to offer in this context for feminism focuses on the subject-in-process, a position which challenges the Enlightenment ideal of the subject as sovereign and rational. Indeed, Europe as an ideal, embracing democracy, the free flow of capital and the rational subject of the Enlightenment has become hotly contested in contemporary politico-economic culture, and that contestation can in part be met by utilizing ideas about the subject and about diversity as they have emerged from feminist thinking. This is important in a context where the decline of European nation states has led to a wave of nostalgia, accompanied by the rise of the new right and micro nationalisms. There is thus a need to develop a post-nationalist sense of European identity through shifts in the sociocultural imaginary as much as through material (re)formations, and it is here that the concept of the feminist subject-in-process and its attendant transformations are useful. ${ }^{6}$

The concept of the subject-in-process, critical to the notion that it is possible to change inequalities, is a key aspect of Women's Studies' emphasis on the importance of women's contribution to and participation in the production of knowledge and thus wealth, a recognition upon which the discipline itself is founded. The European Union itself has recognized this importance through its various emphasis on 'gender' in Framework 6. However, Framework 6 suffers from what one might describe as gender diffusion, that is to say, gender is everywhere (usually as part of a list of dimensions to be borne in mind when conducting research) and therefore potentially nowhere. Researchers under the first call of 17 December 2002 were asked, as part of their proposal, to identify how they have integrated the 'gender dimen- 
sion' into their research. The second paragraph of the explanation of how this might occur, describes the actions which the European Commission wants to pursue:

- Women's participation in research must be encouraged both as scientists/technologists and within the evaluation, consultation and implementation processes,

- Research must address women's needs, as much as men's needs,

- Research must be carried out to contribute to an enhanced understanding of gender issues. ${ }^{7}$

In affirming their commitment to these actions, the European Commission cites articles 2 and 3 of the Treaty of the European Union which enshrine Europe's policies of equal opportunities between women and men. One of the persistent findings of feminist research and national and international statistical analyses, however, are the continuing inequalities between women and men in education and labour market participation rates, in terms of pay, distribution of domestic and care labour, etc. ${ }^{8}$ This despite decades of equality and equal opportunities legislation in most European countries. In fact, as research we conducted as part of the 'Employment and Women's Studies' project ${ }^{9}$ clearly shows, tax incentives and benefit measures aimed at the individual are much more effective in generating change - for instance in women's participation rates on the labour market - than equal opportunities legislation. Legislative initiatives and EC actions by themselves are insufficient and ineffective in achieving the change necessary to utilize women's potential to the full. ${ }^{10}$ Following on from an excellent report on the gender impact in Framework 5,11 in Framework 6 the European Commission has made some incremental changes to its processes and procedures in order to force researcher attention onto the gender issue. However, and critically, whilst the 'gender dimension' in research will now be audited, and some of the restrictions such as the age bar which affect women disproportionately, have been removed, there is no enforcement element that ensures the proper, accountable, realized integration of the gender dimension in research. This impacts detrimentally on women researchers, and unless the EC is prepared to enforce its desired female participation rate of $40 \%$ in research, its auditing will remain a tool for awareness-raising and a measure of the persistent gender gap that continues to haunt all aspects of public and private life, rather than a process by which transformation and gender equality is achieved. There is a need to move from aspiration to implementation, and for the EU to take a lead in this matter.

\section{Gender Mainstreaming}

One reason why Framework 6 suffers from gender diffusion is that the EU has decided on a policy of gender mainstreaming as the measure through which gender equality is to be achieved.12 I do not want to rehearse the arguments for and against gender mainstreaming here, though it is clear that gender mainstreaming is one significant tool in the process of achieving gender equality, but to suggest that this position in part indicates that gender in and of itself is of little interest to the EU. What is of interest is the role of gender in whatever happen to be the key preoccupations of the European Union at a given point in time. Successful applications therefore need to address key current concerns and issues such as the interface between migration and employment, or the question of inter-ethnic conflict resolution, and, in a sense, those need to be put first and gender second. In this context it is very important for gender researchers to consider the make-up of the European Commission, that is the people who work inside it. The public face of the European Union, especially during the early part of 2003, has been that of Germany and France as well as to some extent Italy. 
In the UK, it is the Franco-German alliance against a war in Iraq which is most discussed in the public media, whilst the Nordic and Mediterranean countries hardly feature. The impression thus given is that Europe is dominated by the Franco-German alliance, and in some contexts that may well be true, but when one addresses the Commission what one finds is that many of its employees who are scientific officers and such are in fact from Greece, Spain, the east European and Mediterranean countries, and evaluators of proposals may also come to a significant extent from those countries. One reason is of course that people from these countries speak many languages, certainly many more than the average English person who can barely do more than say a few words in French, if s/he has any language other than English at all. And since the $40 \%$ female participation rate discussed above is still aspirational rather than realized, the likelihood is that the person who will evaluate a proposal submitted by a gender researcher is a man. It is therefore always salutary to ask oneself: 'How would this proposal look to a Greek man, or a Spanish or a Hungarian man?' And it is important to consider what the gender politics in those countries are, what socio-economic priorities they might have, in order to appreciate how they will receive research proposals from gender researchers.

It is here that one of the greatest problems occurs for some gender researchers. Women's Studies as a discipline in diverse European countries has undergone significant changes since its inception from the late 1970s onwards. In the interviews we undertook for the 'Employment and Women's Studies Training' project, this manifested itself most strongly in interviewees' sense, articulated by participants from several countries such as Hungary, the UK, and France, of a divorce between theory and practice, between the academy and activism. One Hungarian woman, for instance, stated that many university women would not attend meetings at NANE (a non-governmental organization dealing with violence against women) for fear of being branded feminist. Another said that the university professors she knew simply were not interested in activism. An Indonesian woman, undertaking an MA in Women's Studies in the UK, described her experience as follows: '[Women's Studies in the UK] is different... a different focus because I think perhaps Indonesia is still struggling with education, with poverty, with working conditions and some things like that. But. . . in the classroom here we don't talk about [that]... we're talking about self identities and things like that that we haven't had the laxity at home to talk about...' (UKCl, pp. 3-4) The difference in focus articulated here, which the student reinforced by commenting on discussions about sexual identity that she had witnessed in UK seminars but which would have been unthinkable in her home country, points to an important development in northern European Women's Studies. Here there has been - within Women's Studies degree courses - an increasing cultural turn, with a focus on issues of identity, sexuality, the role of the cultural in the social, etc. ${ }^{13}$ This has had two inter-related consequences. It has, first, moved Women's Studies agendas significantly away from policy and practice orientation and towards 'high theory'l4 as epitomized by the influence of - importantly key American feminist writers such as Judith Butler and Donna Haraway. Through that shift, secondly, Women's Studies has in some respects inserted itself in the traditional domain of the university, that of theory and abstraction. However, a certain kind of traditional research in traditional universities, focused on theory, is not interesting to the EU which favours concrete policy orientation. Indeed, as Framework 6's distribution of finances with its emphasis on SMEs (small and medium-sized enterprises) and other, non-university part- 
ners makes clear, the EC no longer considers universities to be the only or possibly even major partner in their search for answers to current socio-economic and political issues. In the new knowledge-based society, knowledge can be derived from many sources of which the universities are but one. At a meeting I attended in Brussels last year it was made clear by a member of the Commission that universities are often ineffective and inefficient research partners from the Commission's perspective because they take too long to do the work; they are too inflexible and bureaucratic in their approach as well as too financially demanding; they don't do what they were supposed to do; and they fail to produce practicable policy solutions. In this context Women's Studies, originally committed to a fusion of theory and practice, should have much to offer since it still has the aspiration of an underlying transformative politics that connects theory to the desire for actual change. The attempt to (re)connect with that politics in the context of the European Union and Framework 6 involves in some respects retrenchment from the AngloAmerican dominated cultural turn that Women's Studies has undergone. It raises, itself, many questions about the university's relation to publicly funded, government- or EU-sponsored research, and whether or not researchers in the academy should tailor their research to fit the agendas of nation states and of supra-national entities. At a meeting of project co-ordinators I attended in Lisbon in the autumn of 2002, one of the issues raised was the extent to which policy-oriented research is regarded as inferior in the academy, precisely because of its policy orientation. The responses were mixed but it was clear that in some European countries at least, policy-oriented research was not valued in the academy. This is, of course, partly a function of university histories which emphasize the autonomy of both the institution and the individual researcher from the state apparatus that funds them, linking back to notions of disinterested, objective, ideologically un-invested knowledge production supposedly independent of the state. As research councils and research funders in European countries increasingly set agendas for researchers, not least in the interests of integrating the European Research Area, the idea of autonomous knowledge production recedes in favour of the production of a more knowingly situated knowledge such as feminist standpoint theory, as articulated by Sandra Harding and others, ${ }^{15}$ has already proclaimed.

\section{EUROPEAN DIMENSIONS IN WOMEN'S OR GENDER STUDIES}

Such situated knowledge, within Women's Studies, has also meant - within the European context - that gender researchers, rather than simply follow the Anglo-American lead which has dominated the discipline since its inception, should pause to ask, as indeed the European Union requires researchers to do, "what is the "European dimension" in Women's Studies?' This is not an easy question since the European Union itself is not clear in its own documentation about what it thinks the European dimension is ${ }^{16}$ - supposedly a criterion in evaluating research proposals that are meant to have a 'European added value'. As part of ATHENA, an EU-funded Thematic Network in Women's Studies, ${ }^{17}$ a group of European feminists conducted a series of workshops designed to articulate the 'European dimension' in European Women's Studies. ${ }^{18}$ The participants came from Humanities and Social Sciences backgrounds ${ }^{19}$ which therefore determined the findings of the workshops. Seven areas of feminist work emerged in which one could argue for a specifically European dimension that was different from work in the USA. These clustered around the headings: women as social and political identities; culture and signification; identity, subjectivity 
and difference; race and ethnicity; violence against women; sex/gender terminology and its implications; and, the rises and falls of the women's movements in Europe. ${ }^{20}$

Under 'Women as social and political entities' we focussed on three issues: the decline of the European welfare states and their impacts on women who still figure as most affected by that decline; the rise of the single female as a socio-political entity in Europe and its implications which include a critique of the family as the dominant ideal of micro-social formations and a recognition that new types of social formation such as peer networks which function as quasi-families need to be investigated and understood; and, finally, histories of women's participation in the public sphere and the links between culture and politics. We linked the latter to the notion of 'passion in politics', a notion that is anathema to northern and western European cultures but fundamental to the politics of southern and eastern European states. We argued that there is a need to understand the cartographies of emotions and ideals of passion associated with specific European histories of thought in which the 'active memory of emotions', to quote Luisa Passerini, ${ }^{21}$ is key to the politics of certain European countries, in particular those with histories of fascism and dictatorships. This also raised the significance which psychoanalytic ideas - themselves a specifically European legacy - have in this context and their transformation, especially in Italy and France, into feminist political investment and practice. ${ }^{22}$ In sum we argued that an understanding of the role of passion in politics, not only in southern and eastern European countries, is key to achieving sociopolitical transformation.

In discussing 'Identity, Subjectivity and Difference' in terms of its European dimensions, we focussed on the fact that $\mathrm{Eu}^{-}$ rope, in contrast to the USA and notwithstanding 11 September, has extended recent histories of wars on its soil. We argue that a certain version of Europe, evidenced in the resurgence of macho-nationalism and patriarchy in the eastern states, belongs to men. ${ }^{23}$ As the Hungarian partner in the 'Employment and Women's Studies' project described it:

"Hungary has never had second-wave feminism. Its whole context was missing. 1968 meant Prague for us, not Paris. Its literature was not translated until the late 1990s, its ideology was not known. The changes in 1989 meant an immediate return to a conservative, Christian, nationalist discourse, according to which women were encouraged to return from 'forced communist employment' to the home and raise children."24

This is linked to the decreasing participation of women in the public sphere in post1989 east European countries, ${ }^{25}$ in the erosion of women's rights there, ${ }^{26}$ and in the increasing liminality that women as carriers of national culture experience in states that are themselves liminal to Europe. Indeed, Svetlana Slapsak argues for the need of women from east European countries to forge alliances with women from Third World countries and with subaltern feminist studies as a way of understanding the post1989 situation in the east European countries. $^{27}$

\section{RACE AND ETHNICITY IN EUROPE}

The recognition that women in eastern Europe might have greater affinities with women from Third World countries than with women from northern European countries raises the spectre of diversity in Europe. Diversity or difference, a key concept in contemporary feminism, ${ }^{28}$ is important not only in understanding the construction of the subject, and hence of citizenship, in Europe but also to the issue of how race and ethnicity function in Europe since these are not predicated upon the binary of visible difference - black and white - as it is configured in the USA but, equally 
murderously and more complexly, upon the visibilization of a difference that is not visible. The issue of 'othering' one's neighbour, prominent as much in the Holocaust as in the ethnic cleansing that dominated the Balkan wars of the 1990s, is eminently European. It raises questions about the role of feminism in anti-Semitism, for example. ${ }^{29}$ It also relates to the very different models of integration/assimilation/alienation that govern diverse European countries' relations to their immigrant populations compared to the 'melting pot' model of the USA. ${ }^{30}$ Finally, it relates to the ways in which whiteness, associated with nationalist politics and eugenics, figures in the European imaginary. ${ }^{31}$ In Framework 6 research space is given to the issue of migration, through research topics on 'European citizenship and multiple identities', and on 'Cultural dialogue and the European society'. These research topics speak directly to the diversity which is Europe and to the need for mediation as the basis for any kind of social cohesion within Europe. Women's Studies has long recognized the issue of negotiating multiple identities as they arise for women, and has thus both the conceptual and methodological tools to make significant contributions to research in this area.

Migration and ethnic diversity have shaped not only the recent history of Europe but they have also been the sources of significant cultural clashes, violence, and upheaval. Of particular concern, from a feminist perspective, is violence against women. In the USA and in northern European countries research on that violence has tended to assume a model of domestic violence as it occurs within a stable society. The emphasis in the USA has been on 'the family' as the site for intervention whereas in $\mathrm{Eu}^{-}$ rope it has tended to be on gender relations and on human rights. ${ }^{32}$ This is in line with changing micro-social formations. European legislation has been of paramount importance in improving women's situa- tion regarding violence. In the context of ethnic cleansing which in the Balkans constituted a direct attack on the family we see the resurgence both of the nationalistic impulses that informed earlier forms of genocide in Europe but also the rise of a new indifference towards such crimes that use women's bodies as a battlefield. These histories, as much as contemporary concerns about the trafficking of women as sex workers across the eastern and southern borders of Europe, mean that it is important to understand violence against women not only within stable but also within unstable societies in a recognition that Europe is not internally stable but consists of more and less stable terrains. Jalna Hanmer talks of 'badly lived heterosexuality' to foreground the issue of stationing military personnel in proximity to civil communities and the impact these bases have on such communities. ${ }^{33}$ As Europe moves towards enlargement, and under current global political conditions, we need to develop a much more sophisticated understanding of violence in un/stable, even if highly developed, societies. Research relevant to this could be conducted both in the context of 'European citizenship and multiple identities', and 'Cultural dialogue and the European society' in Priority 7 of the first call of Framework 6.

These topics also offer themselves for the exploration of the relationship between language, culture and (gender) politics which the ATHENA Network had already begun to work on. xxxiv In Thinking Differently we argued that the explosion of the sex/gender $=$ biology/nature binary during the 1990s has facilitated the installation of 'gender' into political and theoretical discourses during that same period, leading to the (re)invisibilization of women whose material conditions have remained, in many ways, unchanged in terms of issues such as the pay gap, care responsibilities, etc. Such installation is not only a function of the un- 
derstanding that some men, as much as women, suffer from depressed socio-economic conditions and from social exclusion but also related to the fact that the concept of equality between women and men has different philosophical and ideological traditions in the diverse European countries. Thus both Finland's insistence on gender neutrality in its policies and France's long tradition of égalité which proclaims an universal subject and thus does not recognize gender difference, have made it difficult for gender inequalities to be effectively addressed in those countries because their respective discourses on the subject do not allow the articulation and thus the recognition of those inequalities. Europe, in all its myriad manifestations, has a long way to go before the persistent gender inequalities which characterize the lives of its populations are eradicated.

\section{CONCLUSIONS}

As gender researchers contemplate participation in Framework 6, they face many challenges. These stem not only from the need to subsume their research interests under the research needs which the European Union has identified as primary to its socio-economic development. They also relate to the kinds of instruments, or collaborative ways of conducting research, which Framework 6 favours and the ways in which funding regimes are changing. Increasingly, and especially as enlargement becomes a reality, EU funding pots for research diminish per head of the population, and, equally increasingly, both national and international funders look for co-funding and matching funding, preferably from the private sector, to support research. Seeking funding through multiple applications to support one project can thus become a fulltime occupation for academics who usually have both teaching and administrative demands in addition to their research requirements to fulfil. If, as is the case with female academics, they are in addition burdened with the lion's share of all care and domestic work to be undertaken, it becomes difficult to see how research can be maintained. In the project on 'Employment and Women's Studies Training', interviewees from all the nine participating European countries repeatedly and emphatically highlighted the fact that the issue of combining career and family was generally viewed as a women's issue. Countries such as Italy and Slovenia reported that women in some employment contexts were asked to sign contracts stating that they would not have children within a given period if they were employed. Such contracts are, of course, illegal but they serve to indicate prevailing sociocultural norms that view women as virtually solely responsible for domestic care duties. Our project made very clear that there is a powerful need to re-write both the social and the domestic contract to make women and men equally responsible in the public and the private sphere. The European Union has a major role to play in enabling this change to take place. The impact of the minimum wage legislation which has been a positive measure for women since it is predominantly women who are employed in low-wage jobs indicates the power of the European Union to effect change. It is this power which needs to be utilized to the benefit of both women and men. This means not only relevant legislation and tax and benefit incentives but also, equally importantly, auditing and enforcement. Without the last, the first two remain ineffective. Gender researchers here have the opportunity to influence European Union agendas both through participating in the consultative exercises the Union undertakes and through the research it funds. They can thus bring their transformative agendas to bear on the European Union's equally transformative agendas. This is the impetus that should fuel gender research in Europe. 


\section{NOTER}

1. Alan Thomson. "'Mickey Mouse" row revived', Times Higher Education Supplement [THES], 14 February 2003, p. 2.

2. The question of whether to use 'Women's' or 'Gender Studies' for degree courses is in part historically determined - in the 1970s the focus was very much on women and early institutionalization of the discipline therefore led to the use of the term 'Women's Studies' in the relevant countries whereas the possibility of 'Gender Studies' was much more a phenomenon of the 1990s and of the Nordic countries with their specific focus on equality. I refer to both terms interchangeably here because in my view the difference in terminology has not led to a difference in emphasis or preoccupation at the level of course content, despite fears of this by early feminists.

3. In an EU-funded research project on 'Employment and Women's Studies'

(www.hull.ac.uk/ewsi) we found that the establishment of Women's Studies was hardest to achieve in countries where rigid disciplinary structures prevail, and where there is a low degree of individual university autonomy. Modular degree structures, possibilities of interdisciplinarity, and state feminism, on the other hand, all favour the institutionalization of Women's Studies. But even with those support structures in place, no European country, not even the Netherlands, the UK or the Nordic countries, has granted Women's Studies equal status with other disciplines as expressed through subject recognition by educational and ministerial funding and assessment bodies, fully endowed departments and professorships, etc. 4. 'Gender research' includes research on men and masculinities which may or may not be feminist in its inception. I use both 'gender research' and 'feminist research' in this article since in fact much 'gender research' is feminist and is about women and also to indicate that research on, for instance, adolescent males and social exclusion, has also become very important in European Union-funded research.

5. Workprogramme, Priority 7, First Call, Citizens and Governance in a Knowledge Based Society, www.cordis.lu/Framework 6

6. For further elaborations on this issue see G. Griffin and R. Braidotti, eds. Thinking Differently: A Reader in European Women's Studies (London: ZED Books, 2002), esp. the introduction.

7. Guide for Proposers, Priority 7, STREPs, $1^{\text {st }}$ call, 17 Dec. 2002 , p. 45 . Credit must be given to the Women and Science Unit of the European
Commission, under the extremely able leadership of Nicole Dewandre, for the inclusion of the gender dimension in Framework 6.

8. See, for example, EUROSTAT, www.oecd.org for details of those inequalities.

9 See www.hull.ac.uk/ewsi for further details.

10. See the comparative data reports on equal opportunities and employment at

www.hull.ac.uk/ewsi (available from October 2003).

11. Braithwaite, Mary. Gender in Research-Gender Impact Assessment of the FP5 Specific Programmes - Improving Human Research Potential and the Socio-Economic Knowledge Base. Brussels: European Commission, Research Directorate, April 2001.

12. See, for instance, the ETAN Expert Working Group's report Science Policies in the European Union: Promoting Excellence through Mainstreaming Gender Equality. Luxembourg: European Communities, 2000.

13. See G.Griffin, 'Co-option or Transformation? Women and Gender Studies Worldwide.' In Heike Flessner and Lydia Potts, eds. Societies in Transition-Challenges to Women's and Gender Studies. Opladen: Leske and Buderich, 2002. 13-32. Also G. Griffin, 'Gender Studies in Europe: Current Directions.' In Luisa Passerini, Dawn Lyon and Liana Borghi, eds. Gender Studies in Europe. Florence: European University Institute, Robert Schuman Centre for Advanced Studies, 2002, pp. 17-30.

14. See Peter Scott's article in this issue in which he differentiates 'mode l' from 'mode 2' knowledge production in the context of an analysis of the modalities of the 'modern' versus the 'postmodern' university.

15. See, for example, Sandra Harding, Feminism and Methodology, Bloomington: Indiana University Press, 1987; and Sharlene Hesse-Biber et al, Feminist Approaches to Theory and Methodology, Oxford: Oxford UP, 1999.

16. This very issue is at present the object of an EU-funded research project (see www.eu-dimension.uni-bremen.de).

17. This network was established by Rosi Braidotti from the University of Utrecht. After the successful completion of the three-year run of the first network, in 2003 the network is submitting an application for ATHENA II to the European Commission.

18. This process resulted in a volume entitled Thinking Differently: A Reader in European Women's Studies (eds. G. Griffin and Rosi Braidotti, London: ZED Books, 2002). 
19. In many European countries Women's or Gender Studies still does not exist as a degree-awarding discipline in its own right. Instead, gender researchers offer modules or short courses on gender topics as part of the traditional disciplines in which they are located.

20. These findings were published in G. Griffin and R. Braidotti, 2002.

21. Elena Pulcini and Luisa Passerini, 'European Feminine Identity and the Idea of Passion in Politics,' in Griffin and Braidotti, 2002, pp. 97-109. 22. Serena Sapegno, 'Psychoanalysis and Feminism: A European Phenomenon and Its Specificities', in Griffin and Braidotti, 2002, pp. 110-26. 23. See, for instance, Peggy Watson, 'The Rise of Masculinism in Eastern Europe', in Monica Threlfall, ed. Mapping the Women's Movement. London; Verso, 1996, pp. 216-31.

24. Unpublished qualitative data report from Hungary by Borbála Juhász, 2003, p. 7.

25. Eva Bahovec et al report the huge discrepancy in female and male representatives that have been elected to the Slovenian parliament since 1990 when the first multi-party election was held (in G. Griffin, ed., Women's Employment, Women's Studies and Equal Opportunities 1945-2001, University of Hull, 2002, p. 306). See also Women in Politics in the Council of Europe Member States, Strasbourg: Directorate General of Human Rights, 2001.

26. See Maxine Molyneux, 'Women's Rights and the International Context in the Post-Communist States', in Monica Threlfall, ed. Mapping the Women's Movement. London: Verso, 1996, pp. 232-59.

27. Svetlana Slapsak, 'Identities under Threat on the Eastern Borders', in Griffin and Braidotti, 2002, pp. 145-57.

28. This is epitomized in the eponymous journal difference/s as much as in many feminist works on difference.

29. See Liliane Kandel, 'Feminism and Anti-Semitism', in Griffin and Braidotti, 2002, pp. 183-204. 30. See Sandra Ponzanesi, 'Diasporic Subjects and Migration', in Griffin and Braidotti, 2002, pp. 205-220.

31. See G. Griffin with R. Braidotti, 'Whiteness and European Situatedness', in G. Griffin and R. Braidotti, 2002, pp. 221-38.

32. See Carole Hagemann-White, 'Violence against Women in the European Context: Histories, Prevalences, Theories', in G. Griffin and R. Braidotti, 2002, pp. 239-51.

33. See Jalna Hanmer, 'Violence, Militarism and War', in G. Griffin and R. Braidotti, 2002, pp. 267-84.
34. See, for example, the four volumes The Making of European Women's Studies, ed. Rosi Braidotti et al, University of Utrecht, and R. Braidotti, 'The Uses and Abuses of the Sex/Gender Distinction in European Feminist Practices', in G. Griffin and R. Braidotti, 2002, pp. 285-310.

\section{LITTERATUR}

- Braidotti, R. (2002): The Uses and Abuses of the Sex/Gender Distinction in European Feminist Practices, in Griffin and Braidotti (eds.). - Braithwaite, Mary (2001): Gender in Research Gender Impact Assessment of the FP5 Specific Programmes - Improving Human Research Potential and the Socio-Economic Knowledge Base. European Commission, Research Directorate, Brussels.

- ETAN Expert Working Group (2000): Science Policies in the European Union: Promoting Excellence through Mainstreaming Gender Equality. European Communities, Luxembourg. . Griffin, G., ed., (2002): Women's Employment, Women's Studies and Equal Opportunities 19452001. University of Hull.

Griffin, G. (2002a): Co-option or Transformation? Women and Gender Studies Worldwide, in Flessner, Heike and Potts, Lydia (eds.) Societies in Transition - Challenges to Women's and Gender Studies. Leske and Buderich, Opladen.

- Griffin, G. (2002b): Gender Studies in Europe:

Current Directions, in Luisa Passerini, Dawn Lyon and Liana Borghi (eds.) Gender Studies in Europe. European University Institute, Robert Schuman Centre for Advanced Studies, Florence.

- Griffin, G. and Braidotti, (eds) (2002): Thinking Differently: A Reader in European Women's Studies. ZED Books, London.

. Griffin, G., with R. Braidotti (2002): Whiteness and European Situatedness, in Griffin and Braidotti (eds.).

- Hagemann-White, Carole (2002): Violence against Women in the European Context: Histories, Prevalences, Theories, in Griffin and Braidotti, (eds.).

- Hanmer, Jalna (2002): Violence, Militarism and War, in Griffin and Braidotti (eds.).

- Harding, Sandra (1987): Feminism and Methodology. Indiana University Press, Bloomington .

- Hesse-Biber., Sharlene et al (1999): Feminist Approaches to Theory and Methodology. Oxford UP, Oxford.

- Kandel, Liliane (2002): Feminism and Anti-Semitism, in Griffin and Braidotti (eds.).

- Molyneux, Maxine (1996): Women's Rights and 
the International Context in the Post-Communist States, in Monica Threlfall (ed.) Mapping the Women's Movement. Verso, London.

- Ponzanesi, Sandra (2002): Diasporic Subjects and Migration, in Griffin and Braidotti (eds.). - Pulcini, Elena and Luisa Passerini (2002): European Feminine Identity and the Idea of Passion in Politics, in Griffin and Braidotti (eds.), 2002. - Sapegno, Serena (2002): Psychoanalysis and Feminism: A European Phenomenon and Its Specificities, in Griffin and Braidotti (eds.).

- Slapsak, Svetlana (2002): Identities under Threat on the Eastern Borders, in Griffin and Braidotti (eds.).

. Thomson, Alan (2003): "Mickey Mouse" row revived, Times Higher Education Supplement

[THES], 14 February 2003, p. 2.

- Watson, Peggy (1996): The Rise of Masculinism in Eastern Europe, in Threlfall, Monica (ed.) Mapping the Women's Movement. Verso, London.

\section{SUMMARY}

The article explores the integration of gender and gender research into the new Framework 6 programme of the European Union. It is argued that the similarities between women's and gender studies and the European Union consists in the fact that they are both transformative projects. Both share a common interest in interdisciplinarity as a way of achieving new knowledge and creating new research. Women's and gender studies offers new conceptual frameworks within which to understand the European citizen in the context of the gendered nature of European key institutions, the welfare state and family, race, ethnicity and strategies of integration and alienation. Finally gender studies in the European framework contributes to the understanding of the notion of 'the European dimension' which the EU seeks to foster in research. In spite of the issues involved in meeting the changing funding regimes of the European Research Programme, gender researchers are encouraged to participate and to bring in their transformative agendas into the consultative exercises and into future EU research.

Gabriele Griffin, $\mathrm{PhD}$, professor Department of Gender Studies University of Hull, UK 